\title{
Soil Management Affects Shoot and Root Growth, Nutrient Availability, and Water Uptake of Young Peach Trees
}

\author{
D.M. Glenn ${ }^{1}$ and W.V. Welker ${ }^{2}$ \\ U.S. Department of Agriculture, Agricultural Research Station, Appalachian Fruit Research \\ Station, Kearneysville, WV 25430 \\ Additional index words. $\quad$ cover crop, tall fescue, rhizotrons, Festuca arundinaceae, Poa trivialis
}

\begin{abstract}
We determined how differences in peach tree water use and shoot and root growth due to ground cover treatments are affected by tree response and soil conditions in the adjacent soil environment. Ground cover combinations of bare soil (BS), a killed K-31 tall fescue sod (KS), a living Poa trivialis sod (PT), and a living K-31 tall fescue sod (LS) were imposed on $50 \%$ of the soil surface in greenhouse studies. The ground cover on $50 \%$ of the soil surface influenced root and top growth of the peach trees [Prunus persica $(\mathrm{L})$ Batsch], water use, and $\mathrm{NO}_{3}-\mathrm{N}$ levels in the opposing 50\%, depending on the competitiveness of the cover crop (LS vs. PT and KS) and characteristics of the soil (BS vs. KS). Tree growth was allometrically related to root growth.
\end{abstract}

Deciduous fruit trees grow and develop in heterogeneous soil environments. Orchard soil characteristics vary vertically due to natural soil morphogenesis and horizontally due to management practices, such as the conventional herbicide-strip tree row with a grassed middle and zones wetted by irrigation. Peach tree growth is sensitive to the proximity of sod (Welker and Glenn, 1985), the competitive ability of cover crops and grassed middles (Butler, 1986; Skroch and Shribbs, 1986), and the management of the tree row strip (Hogue and Neilsen, 1987). The impact of management practices, such as drip irrigation and weed control, may extend into nontargeted areas of the soil environment. Our objective was to document how differences in peach tree water use and shoot and root growth due to groundcover treatments are affected by tree response and soil conditions in the adjacent soil environment.

\section{Materials and Methods}

Rectangular rhizotrons (Study 1). Uniform 1.0-cm-caliper peach trees ('Loring' on Halford) were grown in boxes $100 \times 60 \times$ 36-cm (length $\times$ width $\times$ depth) with 1) an LS in which half the soil surface was a well-established living 'Kentucky-31' (K31) tall fescue sod (Festuca arundinacea Schreb.) planted Jan. 1986 or 2) a KS in which the K-31 sod was killed 2 weeks before planting the trees using $5 \% \mathrm{~N}$-(phosphonomethyl)glycine (glyphosate). In each box, BS was the remaining soil surface. The soil was the 'A' horizon of a Hagerstown silt loam (mixed, mesic, Typic Hapludalf). No fertilizer was applied to the soil. A plastic partition embedded $2 \mathrm{~cm}$ deep into the soil separated the two positions within each box and contained the surface irrigation water for each subplot. Trees were planted in Mar. 1986 in the middle of each box, so that each tree touched the plastic partition in the BS section of each box,

The experimental design was a split plot-the box was the main plot (KS and BS vs. LS and BS) and position within the box the subplots (beneath BS vs. beneath the ground cover)-

Received for publication 14 Nov. 1989. Mention of a trademark or proprietary product does not constitute a guarantee or warranty of the product by the USDA and does not imply its approval to the exclusion of other products that may also be suitable. The cost of publishing this paper was defrayed in part by the payment of page charges. Under postal regulations, this paper therefore must be hereby marked advertisement solely to indicate this fact.

'Soil Scientist.

${ }^{2}$ Weed Scientist. with five replicates arranged in a randomized block design. Each box had a 5.4-cm-diameter plastic tube horizontally installed 18 $\mathrm{cm}$ beneath the midpoint of each half of the ground-cover combination (subplot). These tubes (two per box) served as access tubes for a neutron probe (Campbell Pacific Nuclear, Martinez, Calif.). The field-capacity value of each subplot was determined with the neutron source positioned in the center of the subplot area before the trees were planted. After planting, moisture readings were made three times per week. Six liters of water was added to a subplot when the moisture level was $<90 \%$ of field capacity. Cumulative water use was tabulated until the trees were so large that all subplots required irrigation three times per week.

Samples of soil water were collected using a 2-cm-diameter ceramic cup vacuum soil solution extractor. Ceramic cups $4 \mathrm{~cm}$ long were placed $15 \mathrm{~cm}$ deep (two extractors per box) near the middle of each subplot. Nitrate-nitrogen was analyzed using a selective ion electrode; these data were analyzed in a split-splitplot analysis, with sampling date as the main plot, box as the subplot, and position within box as the sub-subplot. All twoand three-factor interactions were significant; therefore, the data were analyzed for each date.

Six soil blocks $(\approx 4$ liter $)$ were removed from each subplot when the study was terminated in July 1986 . The blocks were collected 10 and $40 \mathrm{~cm}$ from the tree and at depths of $0-12$, 12-24, and 24-36 cm (12 samples per box). The dimensions of each block were recorded to determine soil volume. The roots were washed using an elutriation technique (Smucker et al., 1982) and peach root length (in centimeters) was determined using the modified line intersect method of Tennant (1975). Peach roots counted within the fescue sod area were distinguished from grass roots by color differences and branching habit. For data analysis, the mean subplot root length density (centimeter of root length/cubic centimeter of soil) was calculated using six samples per subplot. Root length was determined for fine peach roots $<1 \mathrm{~mm}$ (FRLD) and large peach roots $>1$ $\mathrm{mm}$ (LRLD) in diameter. Mean separation was based on Duncan's multiple range test $(P=0.05)$.

A soil sample $(\approx 8$ liter) was collected from the center of each

\footnotetext{
Abbreviations: BS, bare soil; FRLD, fine-root length density; KS, killed K-31 tall fesuce sod; LRLD, large-root length density; LS, living K-31 tail fescue sod; PT, living Poa trivialis sod.
} 
treatment for $\mathrm{pH}$ analysis (1:1 in $\left.0.01 \mathrm{M} \mathrm{CaC1}_{2}\right)$; exchangeable $\mathrm{Ca}, \mathrm{Mg}$, and Kin neutral ammonium acetate (Thomas, 1982); organic carbon based on loss of carbon on ignition (Davis, 1974); and acid labile P (Nelson et al., 1953). Above-ground tree ovendried weight and leaf area (LI-COR Model 3050; LI-COR, Lincoln, Neb.) were measured at the conclusion of the study. Mean separation was based on Duncan's multiple range test at ( $P=$ $0.05)$.

The main plot $\mathrm{x}$ subplot interaction was significant for FRLD, $\mathrm{NO}_{3}-\mathrm{N}, \mathrm{P}$, and water use. An LSD was calculated for differences between subplots for different main-plot treatments. This LSD was used as the basis for mean separation using Duncan's multiple range test $(P=0.05)$, where appropriate.

Four-section rhizotrons (Study 2). The treatments consisted of trees grown in boxes (Fig. 1) with all nonrepeating pair-wise combinations of four soil treatments: BS, LS, KS, and PT. Grasses were planted in Feb. 1986 and the K-31 was killed in late March to develop the $\mathrm{KS}$ treatment. Each soil treatment was randomly arranged in two of the four sections of each rhizotron (see Table 3). The soil was a Hagerstown silt loam. A plastic partition embedded $2 \mathrm{~cm}$ deep into the soil contained the surface irrigation water in each section of the rhizotron. Uniform 1.0-cm-caliper peach trees of self-rooted 'Tennessee Natural' were planted in Apr. 1986 in. the center section of each rhizotron. The center section was kept as a bare soil. As. the tree grew, it had equal opportunity to develop roots in the four sections of the rhizotron. A 5.4-cm-diameter plastic tube was horizontally installed in the center of each section and served as an access tube for the neutron moisture probe. The field capacity value of each treatment was determined with the neutron source positioned in the center of the treatment section before the trees were planted. Soil moisture readings were made three times per week. Two liters of water was added to each section when the moisture level was $<90 \%$ of field capacity. Cumulative water use was tabulated until the trees were so large that all treatment combinations required irrigation three times per week.

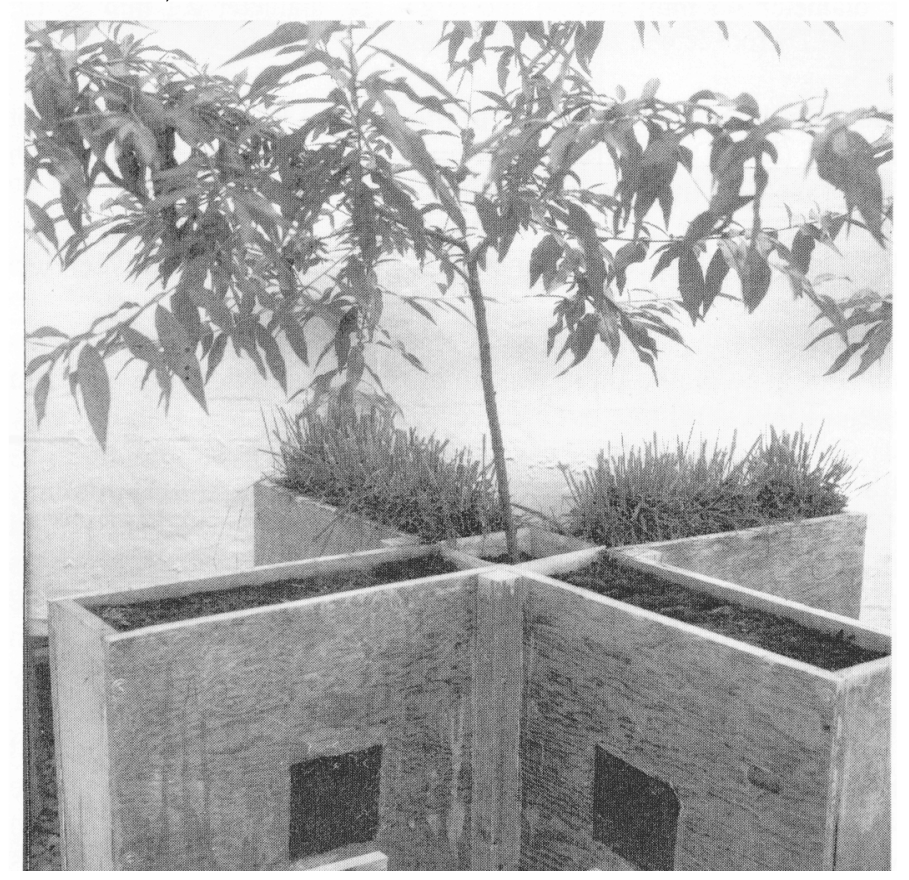

Fig. 1. A four-section rhizotron. Each section is $52 \times 5 \times 50 \mathrm{~cm}$ (length $\times$ width $\times$ depth).
Soil water samples were collected as in study 1 . When the study was terminated in Sept. 1986, nine $218-\mathrm{cm}^{3}$ soil cores were collected from each treatment section. The cores were collected 9, 27, and $45 \mathrm{~cm}$ on center from the central section where the tree was planted and at 9-, 27-, and 45-cm depths, measured on center. Root samples were washed and measured as in study 1 . For data analysis, the mean peach root length density for each treatment was calculated for the two sections of each treatment in each rhizotron (18 samples/treatment). A soil sample of $436 \mathrm{~cm}^{3}$ was collected from the central portion of each section and analyzed for soil chemical properties as in study 1. Above-ground tree oven-dried weight and leaf area were measured at the conclusion of the study. During the study, the grass in the LS treatments was mowed monthly to a $3-\mathrm{cm}$ height. The slow-growing grass in the PT treatment was not mowed. No fertilizer was added to any treatment.

The experimental design for soil chemical characteristics and root length density was a randomized complete block, with two replicates in which the treatments were designated as the area where data were collected in combination with the opposing treatments in the rhizotron. Therefore, each four-section rhizotron contained two treatments (see Table 3). Data on tree oven-dried weight and leaf area were analyzed using each rhizotron in a randomized complete-block design with two replicates. Duncan's multiple range test $(P=0.05)$ was used to separate treatment means for water use, soil solution $\mathrm{NO}_{3}-\mathrm{N}$, and tree growth. A protected LSD $(P=0.05)$ was calculated for the treatment effects on fine- and large-root length density.

\section{Results and Discussion}

Rectangular rhizotrons. Peach trees grown in boxes containing BS-KS grew significantly more than trees grown in BS-LS (Table 1). FRLD was greater in the KS than in BS of the BSKS treatment. However, in the BS-LS treatment, FRLD was greater in BS than in LS (Fig. 2). The overall LRLD was greater

Table 1. Effect of BS combined with KS or LS on peach tree growth in rectangular rhizotrons.

\begin{tabular}{|c|c|c|}
\hline Treatment & $\begin{array}{l}\text { Total above-ground } \\
\text { oven-dried wt } \\
\text { (g) }\end{array}$ & $\begin{array}{l}\text { Leaf area } \\
\left(\mathrm{m}^{2} / \text { tree }\right)\end{array}$ \\
\hline $\begin{array}{l}\text { BS-KS } \\
\text { BS-LS }\end{array}$ & $\begin{array}{r}208 \mathrm{a} \\
83 \mathrm{~b}\end{array}$ & $\begin{array}{l}2.52 \mathrm{a} \\
0.86 \mathrm{~b}\end{array}$ \\
\hline
\end{tabular}

${ }^{2}$ Means separation within columns based on a paired $t$ test, $P=0.05$

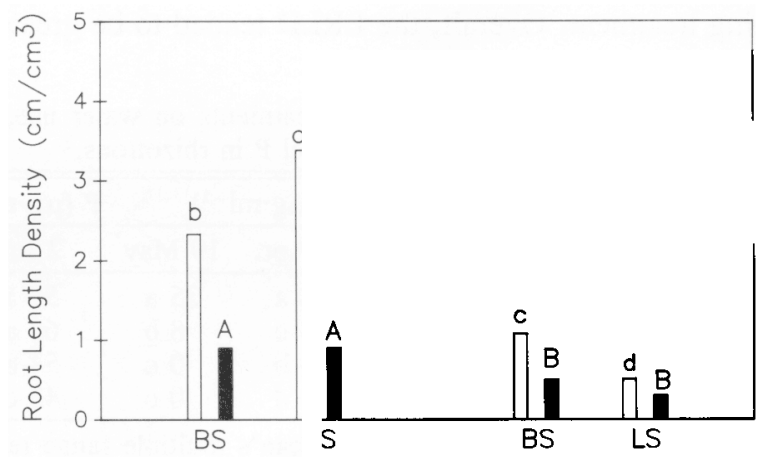

Fig. 2. Effect of BS, KS, and LS treatments on fine- ( $\mathrm{q}$, diameter $<1 \mathrm{~mm}$; FRLD) and large- $(\mathrm{n}$, diameter > $1 \mathrm{~mm} \times 10$; LRLD) root length density. Mean separation by Duncan's multiple range test, $P=0.05$. 
in rhizotrons with BS-KS than with BS-LS; however, LRLD was unaffected by position within the rhizotrons. We have found similar results in a previous greenhouse study examining the BS and LS effects on peach root growth (Glenn and Welker, 1989). Water use with LS was greater than with $\mathrm{KS}$, which was greater than with BS (Table 2). In the BS-KS rhizotron, water use in each subplot was correlated with FRLD ( $r=0.60, P=0.05)$.

Soil solution $\mathrm{NO}_{3}-\mathrm{N}$ decreased over time in all treatments (Table 2). Nitrate-nitrogen levels in the LS were always lower than in the other sampled positions. Nitrate-nitrogen availability limited top and root growth of the peach tree in the LS compared to the BS position within the rhizotron. The $\mathrm{NO}_{3}-\mathrm{N}$ interaction in BS on 20 Apr. and 19 May can be explained, in part, by the growth and nutrient uptake of encroaching grass roots at the 10$\mathrm{cm}$ distance, in the BS area of the BS-LS treatment. Similarly, the presence of grass roots in the BS of the BS-LS treatment would largely explain the similar water use rates (Table 2) of BS when the FRLD was reduced $53 \%$ for BS-LS compared to BS-KS (Fig. 2).

KS had the highest level of available $\mathrm{P}$ and LS the lowest (Table 2). The BS areas showed an interaction with their adjacent ground-cover treatment: P levels were lower in LS when adjacent to BS than when next to KS. Peach root growth (FRLD and LRLD) was inhibited beneath or adjacent to LS, and lower levels of available soil $\mathrm{P}$ and $\mathrm{NO}_{3}-\mathrm{N}$ were evident under $\mathrm{LS}$ as a result of the combined peach and grass root systems. Soil analysis at the conclusion of the study indicated there was no significant treatment effect on soil $\mathrm{pH}$, soil organic matter, or soil $\mathrm{K}, \mathrm{Ca}$, or $\mathrm{Mg}$ (data not shown).

Peach tree root growth was stimulated beneath the KS cover, which accounts for the greater water use in the KS area compared to the BS treatment. We partially attribute the increased FRLD in the KS to soil structural characteristics since we found no difference in soil chemical characteristics, except $\mathrm{NO}_{3}-\mathrm{N}$ between the BS and $\mathrm{KS}$ in the BS-KS treatment. Welker and Glenn (1988) have shown that the KS improves soil structure and porosity compared to BS.

Four-section rhizotrons. Tree growth was greatest with a combination of BS and KS, the least with LS and PT (Table $3)$. The presence of LS or PT in 50\% of the root box surface reduced tree growth compared to the BS-KS treatment. FRLD in BS was greater when paired with KS or PT than when paired with LS (Fig. 3). FRLD in KS was greater when paired with BS and PT than with LS. BS-KS had the highest FRLD, as it did in study 1. FRLD in LS and PT treatments was not significantly affected by the opposing treatment combinations. LRLD in any $50 \%$ portion of the root volume was unaffected by the opposing treatment. Overall, the LRLD tended to be greater in

Table 2. Effect of BS, KS, and LS treatments on water use, soil solution $\mathrm{NO}_{3}-\mathrm{N}$ levels, and available soil $\mathrm{P}$ in rhizotrons. ${ }^{\mathrm{z}}$

\begin{tabular}{|c|c|c|c|c|c|}
\hline \multirow{2}{*}{ Treatment } & \multirow{2}{*}{$\begin{array}{c}\text { Water use } \\
\text { (liters/97 days) }\end{array}$} & \multicolumn{3}{|c|}{$\mathrm{NO}_{3}-\mathrm{N}\left(\mu \mathrm{g} \cdot \mathrm{ml}^{-1}\right)$} & \multirow{2}{*}{$\frac{\mathrm{P}\left(\mu \mathrm{g} \cdot \mathrm{ml}^{-1}\right)}{2 \mathrm{July}}$} \\
\hline & & $10 \mathrm{Apr}$ & 29 Apr. & 19 May & \\
\hline BS & $84 \mathrm{c}$ & $658 \mathrm{a}$ & $58 \mathrm{a}$ & $25 \mathrm{a}$ & $57 \mathrm{ab}$ \\
\hline$K S^{y}$ & $122 \mathrm{~b}$ & $303 \mathrm{~b}$ & $18 \mathrm{c}$ & $8 \mathrm{~b}$ & $63 \mathrm{a}$ \\
\hline BS & $93 \mathrm{c}$ & $600 \mathrm{a}$ & $30 \mathrm{~b}$ & $0 \mathrm{c}$ & $54 \mathrm{~b}$ \\
\hline $\mathrm{LS}^{\mathrm{x}}$ & $191 \mathrm{a}$ & $26 \mathrm{c}$ & $0 \mathrm{~d}$ & $0 \mathrm{c}$ & $43 c$ \\
\hline
\end{tabular}

${ }^{2}$ Mean separation within columns by Duncan's multiple range test, $P$ $=0.05$.

${ }^{y}$ K-31 sod planted 3 Jan. 1986 and killed 24 Feb. 1986 using 5\% glyphosate.

$\mathrm{K}-31$ sod planted 3 Jan. 1986.
Table 3. The effect of four soil management treatments in combination on peach tree growth in four-section rhizotrons. ${ }^{2}$

\begin{tabular}{ccc}
\hline \hline Treatment & $\begin{array}{c}\text { Total above-ground } \\
\text { oven-dried wt } \\
(\mathrm{g})\end{array}$ & $\begin{array}{c}\text { Leaf area } \\
\left(\mathrm{m}^{2} / \text { tree }\right)\end{array}$ \\
\hline BS-KS & $499 \mathrm{a}$ & $4.30 \mathrm{a}$ \\
BS-LS & $307 \mathrm{bc}$ & $2.37 \mathrm{bc}$ \\
BS-PT & $376 \mathrm{~b}$ & $2.98 \mathrm{~b}$ \\
KS-BS & $499 \mathrm{a}$ & $4.30 \mathrm{a}$ \\
KS-LS & $206 \mathrm{c}$ & $1.59 \mathrm{c}$ \\
KS-PT & $362 \mathrm{~b}$ & $2.74 \mathrm{~b}$ \\
LS-BS & $307 \mathrm{bc}$ & $2.37 \mathrm{bc}$ \\
LS-KS & $206 \mathrm{c}$ & $1.59 \mathrm{c}$ \\
LS-PT & $194 \mathrm{c}$ & $1.58 \mathrm{c}$ \\
PT-BS & $376 \mathrm{~b}$ & $2.98 \mathrm{~b}$ \\
PT-KS & $362 \mathrm{~b}$ & $2.74 \mathrm{~b}$ \\
PT-LS & $194 \mathrm{c}$ & $1.58 \mathrm{c}$ \\
\hline
\end{tabular}

${ }^{2}$ Mean separation within columns by Duncan's multiple range test, $P$ $=0.05$.

${ }^{y}$ Treatment values are duplicated to illustrate effects in all possible combinations. Grasses were planted 24 Feb. 1986, and the KS treatment was sprayed with 5\% glyphosate on 24 Mar. 1986.

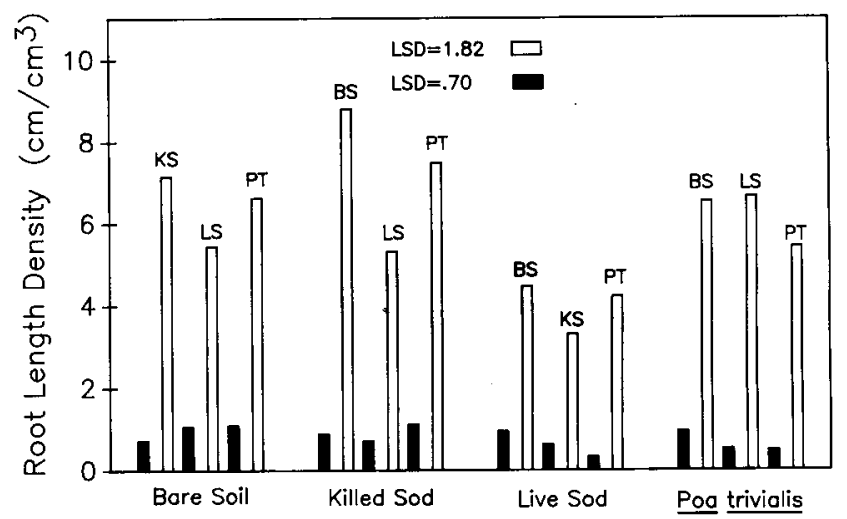

Fig. 3. The effect of BS, KS, LS and PT treatments on fine- ( $\square$, diameter <1 mm; FRLD) and large- ( $\mathbf{\square}$, diameter > $1 \mathrm{~mm} \times 10$; LRLD) root length density. LSD based on $P=0.05$.

the BS and KS portions than in the LS and PT treatments. Root growth (FRLD) and tree dry weight with LS were less than with PT [based on linear contrasts across all opposing treatments $(P$ $=0.05)]$. Tree dry weight was correlated with LRLD $(r=$ $0.52, P=0.05)$, reflecting similar growth patterns between top and roots.

Tree growth, as measured by dry weight, was related to overall root growth and there was an allometric relationship between mean FRLD and tree oven-dried weight for studies 1 and 2 (Fig. 4) Other studies have shown that there is a physiological equilibrium between top and root growth (Lockard and Schneider, 1981). Tan and Buttery (1982) have shown that water supplied in adequate amounts to as little as $50 \%$ of the root system is as effective as supplying the same amount of water to $100 \%$ of the root system. We found that the development of the root system was a more critical factor to young tree growth than the supply of water, since all our treatments were kept well-watered.

Water use in $50 \%$ of the root zone was affected by the soil management system in the opposing $50 \%$ of the root zone (Table 4). Water use in the KS area was higher when opposite BS than when opposite LS or PT, and water use from the KS area was correlated with its FRLD $(r=0.84, P=0.05)$. Water use in LS was higher when opposite BS than when opposite PT. Water 


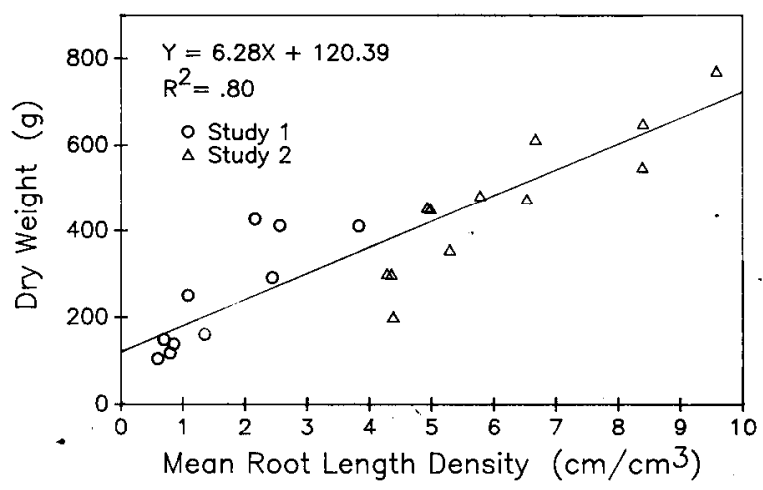

Fig. 4. The allometric relationship between mean peach root length density, and the above-ground tree oven-dried weight.

Table 4. The effect of four soil management treatments in combination on peach water use and soil solution $\mathrm{NO}_{3}-\mathrm{N}$ levels in foursection rhizotrons. ${ }^{2}$

\begin{tabular}{|c|c|c|c|c|}
\hline \multirow[b]{2}{*}{ Treatment } & \multirow{2}{*}{$\begin{array}{l}\text { Opposing } \\
\text { treatment }\end{array}$} & \multirow{2}{*}{$\begin{array}{c}\text { Water use } \\
\text { (liters/50 days) }\end{array}$} & \multicolumn{2}{|c|}{$\mathrm{NO}_{3}-\mathrm{N}\left(\mu \mathrm{g} \cdot \mathrm{ml}^{-1}\right)$} \\
\hline & & & 8 July & $22 \mathrm{Aug}$ \\
\hline BS & KS & $23 b c$ & $163 \mathrm{~b}$ & $20 \mathrm{NS}$ \\
\hline $\mathrm{BS}$ & LS & $27 \mathrm{ab}$ & $75 \mathrm{c}$ & 15 \\
\hline $\mathrm{BS}$ & PT & $26 \mathrm{abc}$ & $200 a$ & 18 \\
\hline $\mathrm{KS}$ & BS & $31 \mathrm{a}$ & $40 \mathrm{~d}$ & 18 \\
\hline $\mathrm{KS}$ & LS & $20 \mathrm{c}$ & $44 \mathrm{~d}$ & 14 \\
\hline $\mathrm{KS}$ & PT & $23 \mathrm{bc}$ & $39 \mathrm{~d}$ & 14 \\
\hline LS & $\mathrm{BS}$ & $31 \mathrm{a}$ & $15 \mathrm{e}$ & 19 \\
\hline LS & $\mathrm{KS}$ & $27 \mathrm{ab}$ & $6 \mathrm{e}$ & 14 \\
\hline LS & PT & $24 \mathrm{bc}$ & $20 \mathrm{e}$ & 13 \\
\hline PT & $\mathrm{BS}$ & $21 \mathrm{bc}$ & $35 \mathrm{~d}$ & 14 \\
\hline PT & $\mathrm{KS}$ & $23 \mathrm{bc}$ & $9 \mathrm{e}$ & 20 \\
\hline PT & $\mathrm{LS}$ & $22 \mathrm{bc}$ & $13 \mathrm{e}$ & 15 \\
\hline
\end{tabular}

${ }^{2}$ Mean separation within columns by Duncan's multiple range test, $P$ $=0.05$.

NSNot significant.

use from the PT and BS treatments was unaffected by the opposing soil management treatments. Water use from the KS area of KS-BS was higher than from BS in the BS-KS treatment, as we found in study 1; water use from the LS area of LS-BS tended to be higher than from BS in the BS-LS combination.

Soil solution $\mathrm{NO}_{3}-\mathrm{N}$ decreased from 8 July to 22 Aug., with BS demonstrating the greatest decline (Table 4). Nitrate-nitrogen levels in BS were initially highest when paired with PT and least with LS, with KS being intermediate. Nitrate-nitrogen levels in KS and LS were unaffected by the opposing treatment at either date. Nitrate-nitrogen levels in PT were initially higher when paired with BS as opposed to being paired with $\mathrm{KS}$ and LS, but showed no difference by 22 Aug. The competitiveness of the cover crops explain, in part, the $\mathrm{NO}_{3}-\mathrm{N}$ levels of 8 July. PT is a slow-growing grass that was not cut during this study. LS was a rapidly growing grass that required monthly cutting. The low levels of $\mathrm{NO}_{3}-\mathrm{N}$ in KS, LS, and PT on 8 July were due to uptake of $\mathrm{N}$ by grass before sample collection. The low $\mathrm{NO}_{3}-\mathrm{N}$ level in $\mathrm{BS}$ of $\mathrm{BS}-\mathrm{LS}$ suggests that the tree was using the $\mathrm{NO}_{3}-\mathrm{N}$ pool of the $\mathrm{BS}$ to a large degree, whereas the BS area of the BS-KS and BS-PT treatments was not the sole source of $\mathrm{NO}_{3}-\mathrm{N}$, as based on their higher $\mathrm{NO}_{3}-\mathrm{N}$ levels on 8 July. Conversely, the elevated $\mathrm{NO}_{3}-\mathrm{N}$ levels in the PT area of PT-BS compared to PT-KS and PT-LS suggests that the higher level of $\mathrm{NO}_{3}-\mathrm{N}$ in $\mathrm{BS}$ reduced the $\mathrm{NO}_{3}-\mathrm{N}$ demand in the PT area.

Soil analysis at the termination of study 2 indicated that soil management treatments only affected soil $\mathrm{pH}$; there were no interactions with the opposing treatment. Soil $\mathrm{pH}$ was significantly lower in all BS treatments than in KS, LS, or PT (5.7, $6.0,6.2$, and 6.1, respectively, $P=0.05$ ). Available $\mathrm{P}$ levels were unaffected by the treatments or treatment combinations (data not shown). The design of the containers in study 2 prevented LS and PT roots from growing into adjacent root zones, and grass roots were not found in the BS treatment areas as they were in study 1.

We found that young peach trees responded to the groundcover treatment combinations. Ground cover on $50 \%$ of the soil surface influenced root growth and $\mathrm{NO}_{3}-\mathrm{N}$ levels in the adjacent $50 \%$ of the root volume, depending on the competitiveness of the cover crop (LS and PT vs. KS) and physical characteristics of the soil (BS vs. KS). The effect of our ground-cover treatments on root and tree growth was not entirely a nutritional effect since 1) BS had significantly higher $\mathrm{NO}_{3}-\mathrm{N}$ levels than the opposing KS in both studies, yet BS had significantly lower FRLD and lower water use; and 2) LS and PT had similar levels of $\mathrm{NO}_{3}-\mathrm{N}$, but PT had a greater FRLD and tree dry weight than LS. Tree growth can not only be influenced by the chemical and physical characteristics of the managed soil area but also by the adjacent soil areas as well.

\section{Literature Cited}

Butler, J.D. 1986. Grass interplanting in horticulture cropping systems. HortScience 21:394-397.

Davis, B.E. 1974. Loss-on-ignition as an estimate of soil organic matter. Soil Sci. Soc. Amer. Proc. 38:150-151.

Glenn, D.M. and W.V. Welker. 1989. Peach root development and tree hydraulic resistance under tall fescue sod. HortScience 24: 117119.

Hague, E.J. and G.H. Neilsen. 1987. Orchard floor vegetation management. Hort. Rev. 9:377-430.

Lackard, R.G. and G.W. Schneider. 1981. Stock and scion growth relationships and the dwarfing mechanism in apple. Hort. Rev. 3:315315 .

Nelson, W. L., A. Mehlick, and E. Winters. 1953. The development, evaluation, and use of soil tests for phosphorus availability. Agron. J. 4:153-188.

Skroch, W.A. and J.M. Shribbs. 1986. Orchard floor management: An overview. HortScience 21:390-394.

Smucker, A. J. M., S.L. McBurney, and A.K. Srivastava. 1982. Quantitative separation of roots from compacted soil profiles by the hydropneumatic elutriation system. Agron. J. 74:500-503.

Tan, L.S. and B.R. Buttery. 1982. The effect of soil moisture stress to various fractions of the root system on transpiration, photosynthesis and internal water relations of peach seedlings. HortScience 107:845-849.

Tennant, D. 1975. A test of a modified line intersect method of estimating root length. J. Ecol. 63:995-1001.

Thomas, G.W. 1982. Exchangeable cations, p. 160-161. In: A.L. Page (cd.). Methods of soil analysis, Part 2. Chemical and microbiological properties. Agron. Monogr. 9. Amer. Soc. Agron., Madison, Wis.

Welker, W.V. and D.M. Glenn. 1985. The relationship of sod proximity to the growth and nutrient composition of newly planted peach trees. HortScience 20:417-418.

Welker, W.V. and D.M. Glenn. 1988. Growth responses of young peach trees and changes in soil characteristics with sod and conventional planting systems. J. Amer. Soc. Hort. Sci. 113:652-656. 